\title{
Synopsis of rare fossil animal spermatozoa in amber and sedimentary deposits
}

\author{
Gérard Breton ${ }^{1,2, *}$ and George Poinar ${ }^{3}$ \\ ${ }^{1} 6$ rue des Réservoirs, 76600 Le Havre, France \\ 2 UMR, CNRS 6118, géosciences, université de Rennes I,35042 Rennes cedex, France \\ ${ }^{3}$ Department of Integrative Biology, Oregon State University, Corvallis, Oregon 97330, USA
}

Received: 25 March 2019 / Accepted: 22 April 2020

\begin{abstract}
Fossil spermatozoa are extremely rare. Among the eight cases reported here, including two cases of spermatophores without visible sperm cells, six are fossils preserved in amber. All six concern animals with indirect sperm transfer by means of spermatophores or spermatodesmids. Preservation of subcellular organelles shows once again that amber is an extraordinary preservation medium.
\end{abstract}

Keywords: spermatozoa / spermatophore / spermatodesmid / fossil / cellular structure preservation / amber

\begin{abstract}
Résumé - Synopsis de rares spermatozoïdes animaux dans l'ambre ou d'autres roches sédimentaires. Les spermatozoïdes fossiles sont très rares. Parmi les huit cas que nous rapportons ici, dont deux cas de spermatophores sans spermatozoïdes visibles, six sont des fossiles conservés dans l'ambre. Les six concernent des animaux pratiquant un transfert indirect des spermatozoïdes par l'intermédiaire de spermatophores ou de spermatodesmes. La préservation d'organites subcellulaires montre une fois de plus que l'ambre est un milieu de conservation exceptionnel.
\end{abstract}

Mots clés : spermatozoïdes / spermatophore / spermatodesm / fossile / préservation de la structure cellulaire / ambre

\section{Introduction}

Vegetal reproductive structures are common in the fossil record: spores, cysts, pollen grains, seeds and fruits are frequently encountered in many kinds of sediments. However, fossil metazoan reproductive structures are nearly limited to mineralized or chitinous eggshells and some nests or various trace fossils, whose potential of fossilization is high. Sperm cells, due to their microscopic size and lack of hard parts, are among the rarest preserved structures as fossils. Kojeta (1998) described "in action inclusions" in amber, i.e. fossilized events of biological importance. He illustrated this notion, among other examples, by scale insects that ejected sperm when entombed in resin, with several cases of spermatophores, but very few cases of (questionable) sperm cells. Only six cases of unquestioned fossil spermatozoa have been published; they are introduced here in chronological order.

\footnotetext{
${ }^{*}$ Correspondence: gerard-breton@orange.fr
}

\section{Spermatophores and questionable spermatozoa produced by coccids preserved in amber Kojeta (1998)}

Margarodids from Baltic amber were shown to exhibit spermatophores and one questionable case of spermatozoa. Monophlebids from Baltic amber and New Jersey amber show spermatophores and possible spermatozoa. The coelostomidiids, Matsucoccus sp. and pytiococcids from Baltic or Bitterfield amber only show spermatophores. Sperm ejection was thought to have been a response to entombment in resin.

\section{Collembola spermatozoa and spermatophores in Baltic Eocene amber from Poland}

Poinar (2000) described, in a piece of amber originating from Poland and authenticated as Baltic amber (late Eocene), two stalked spermatophores and sixteen spermatozoa. The 
preservation was good enough to show cellular details: acrosome, head containing the nuclear body, which extends for a short distance into the tail. The tail is long, straight and contains a thin dark axoneme. A female springtail, Sminthurus longicornis Kock and Berendt 1854, is adjacent to the spermatophore. Its fulcrum, legs, antennae and anal lobe are visible. An egg is attached to the posterior portion of the female's body. Another egg lies behind the female. Poinar (2000) identified the spermatophores and spermatozoa as belonging to springtails, based on data from living collembolans and by the presence of the female springtail adjacent to the spermatophore. He commented on the indirect sperm transfer method by means of stalked spermatophores.

\section{Mymarommatid wasp spermatophore from Lower Cretaceous amber from Spain}

Martínez-Delclòs et al. (2004) showed a picture of spermatophores at the apex of a mymarommatid wasp, but without spermatozoa. As their paper deals with compared taphonomy of insects in carbonates and amber, they do not comment further on this observation.

\section{Giant sperm in fossil Ostracods (Cretaceous from Brazil, Miocene from Australia)}

Matzke-Karasz et al. (2009) demonstrated Zenker organs (o) or post-mating seminal receptacles (o) in Cretaceous cypridid ostracods from Brazil, using phase X-ray synchrotron tomographic mocroscopy. They identified Zenker organs and seminal vesicles, which in this group, indirectly denote the presence of characteristic, aflagellate, filiform giant spermatozoa. Matzke-Karasz et al. (2014) described, in an early Miocene cave deposit from Australia, cypridoidean ostracods with preserved giant spermatozoa. Nanotomography revealed preserved intracellular organelles as helical nuclei and monorails. This exceptional preservation is due to a very early mineralization of the soft parts of the ostracods facilitated by a high-level phosphate content linked to the bat guano. Matzke-Karasz et al. (2014) noted that "fossilized sperm are generally exceptionally rare; the only other record being a springtail trapped in Late Eocene Baltic amber". They quote Poinar (2000) but ignore Breton (2012).

\section{Spermatodesmids in a lowermost Eocene amber from South France}

Breton (2012), ignoring Poinar's (2000) paper, described "the first fossil record" of animal spermatozoa, spermatodesmids and a possible spermatophore in the lower Ypresian amber from Douzens and Caunette-en-Val (Aude department, South France). The resin was secreted in a freshwater to a moist forestry soil environment. Four observations of spermatodesmids (= spermatozeugmata, = bundles of spermatozoa) (Tuzet, 1977) were made, one of a spermatodesmid with spermatozoa heads included in the possible remains of a

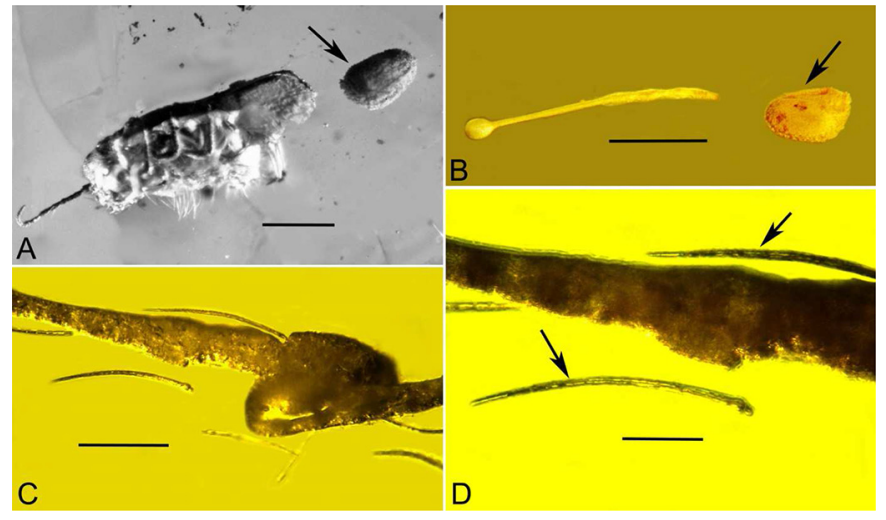

Fig. 1. Sminthurus longicornis Koch and Berendt, 1854 in Baltic amber. A. Sminthurus longicornis depositing an egg. Arrow shows previously deposited egg. Scale bar $=750 \mu \mathrm{m}$. B. Spermatophore of Sminthurus longicornis with terminal sperm droplet. Arrow shows recently deposited egg. Scale bar $=675 \mu \mathrm{m}$. C. Several elongate spermatozoa of Sminthurus longicornis adjacent to a spermatophore. Scale bar $=50 \mu \mathrm{m}$. D. Two spermatozoa (arrows) of Sminthurus longicornis. Scale bar $=24 \mu \mathrm{m}$.

spermatophore, Other observations of isolated sperm cells are described from several amber pieces, one of which had been collected $13 \mathrm{~km}$ distant from Douzens in contemporaneous deposits. The isolated sperm cell and some sperm cells of the spermatodesmids show a beak-like, pointed lateral acrosome, a dark nucleus, a short connecting piece (=mitochondrion) with one complete helical turn, and a thin, whip-like tail. The spermatodesmids comprise several dozen spermatozoa. The possible spermatophore remaining is a bag-like structure covering the heads of the sperm cells, with an opening leaving passage for the bundle of flagella.

\section{Casts of spermatozoa in Eocene clitellate annelid cocoons from Antarctica}

Bomfleur et al. (2015) and McLoughlin et al. (2016a, 2016b) describe fossil spermatozoa embedded in the wall layers of an early Eocene clitellate cocoon (= egg case) from Antarctica. Overlooking Breton's (2012) paper which also describes early Eocene spermatozoa (see above), they state that these fossils are "the oldest fossil animal sperm yet known". These spermatozoa are preserved, together with bacteria and vermiform bodies, as moulds within the hirudoid inner layers of the cocoon. The preservation is good enough to distinguish, under a SEM, an apical button, a tightly coiled acrosome, a granular ornamented nuclear region that tapers distally, a mitochondrial region and a whip-like flagellum. The excellent preservation allows a comparison with the cocoons and sperm cells of living clitellate annelids: the fossil material is thought to belong possibly to branchiobdellids (= crayfish worms).

\section{Ensiferan Orthopteran spermatozoa from mid-Cretaceous Burmese amber}

In ensiferans orthopterans, the male often deposits spermatophores at the tip of the abdomen of the female on or near the female genital opening. The spermatophore normally consist of 


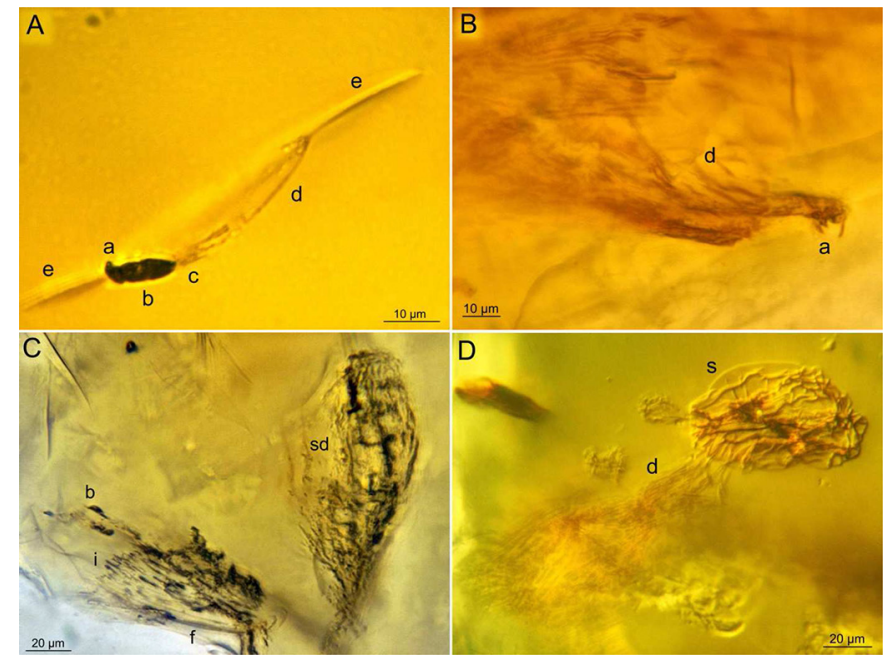

Fig. 2. Spermatozoon, spermatodesmids and spermatophore in Ypresian amber from Southern France: a: acrosome; b: head of the sperm cell containing the nucleus; c: connecting piece; d: flagellum; e: optical section of a crack in the amber, probably induced by the sperm cell; i: immature spermatozoa; s: bag-like likely spermatophore covering the heads of the sperm cells (D); d: poorly preserved spermatodesmid. A. Isolated spermatozoon, unknown producer. B. Spermatodesmid, unknown producer. C. Two spermatodesmids, one poorly preserved, the other with immature 214 spermatozoa, unknown producer. D. Spermatodesmid and possible spermatophore, unknown producer.

two parts, an ampulla with sperm and a spermatophylax. Only the former contains actual sperm while the spermatophylax contains nutritive substances that are ingested by the female during or after mating. This behaviour was documented with a female pygmy mole cricket, Cascogryllus lobiferus Poinar, in midCretaceous Burmese amber (Poinar, 2018). It is presumed that the small packet with developing spermatozoa adjacent to the female fossil was deposited by a male shortly before $C$. lobiferus was entombed in resin. There was no visible sign of a spermatophylax or any other type of nuptial gift in the amber. The spermatozoon adjacent to the fossil (Fig. 1) resembles some figured by Bidau (2014) in his Orthoptera review paper.

\section{Empidid fly spermatophores from Oligo-Miocene Dominican amber}

It is easier to discover insect spermatophores in amber rather than actual spermatozoa. Sometimes, sperm cells can be observed through the wall of the spermatophore if it is not too thick. While studying nematode fossils in amber, Poinar (2011) noted that the elongate spermatophores associated with an adult empidid fly closely resembled free-living stages of nematodes. These spermatophores were emerging from the reproductive system (Fig. 2) and some had clustered together adjacent to the dipteran (Fig. 3).

\section{Conclusions}

The potential for the fossilization of sperm is very low for several reasons. The individual spermatozoa are microscopic

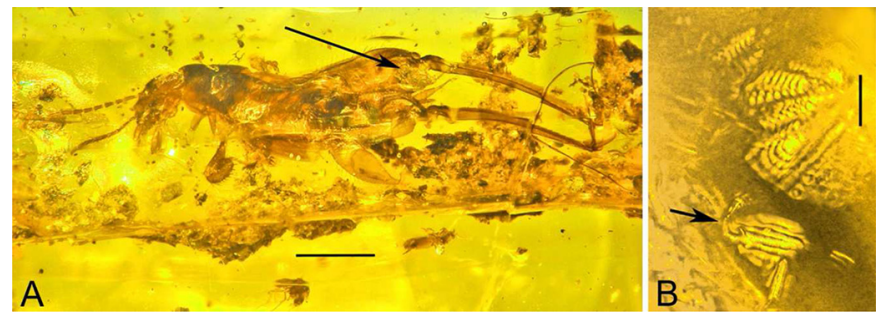

Fig. 3. Cascogryllus lobiferus Poinar, 2018 in Burmese amber. A. Arrow shows location of spermatophores. Scale bar $=1.2 \mathrm{~mm}$. B. Arrow shows a spermatozoon leaving the sperm packet. Scale bar $=98 \mu \mathrm{m}$.

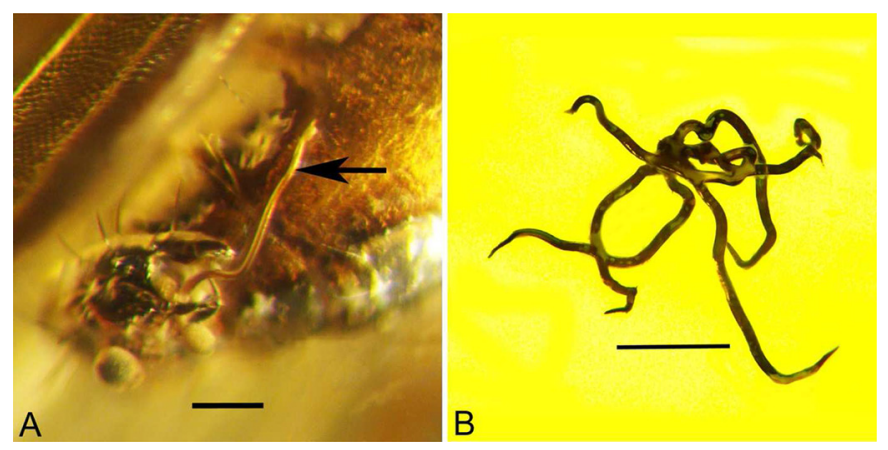

Fig. 4. Spermatophore of a dance fly (Diptera: Empididae) in Dominican amber. A. Spermatophore (arrow) being released from a dance fly. Scale bar $=110 \mu \mathrm{m}$. B. Cluster of spermatophores adjacent to the dance fly. Scale bar $=90 \mu \mathrm{m}$.

cells, devoid of any sclerotized, mineralized or hard part. In all species (either terrestrial or aquatic) with internal fertilization by free sperm or spermatophores, the spermatozoa are never exposed to conditions of fossilization. For the aquatic, mostly marine, species whose gametes are dispersed in the water where fertilization takes place, the spermatozoa are subject to decay before fossilization (Fig. 4).

That is why exceptional conditions are needed to fossilize animal spermatophores or even actual sperm cells. Among the published cases, two concern spermatozoa which had no free life in the environment: the giant sperm cells of fossil ostracods which had benefited from an early phosphate mineralization and the sperm cells embedded in the very resistant organic material of clitellate annelid cocoons.

The other cases are those of animals whose sexual behaviour is an indirect transfer of spermatophores or spermatodesmids. On the substrate where they are deposited by the male, if they are not retrieved by the female, they are likely prone to a quick decay and do not fossilize. Unless a resin flow embeds them! The sperm cells, spermatophores or spermatodesmids embedded in amber are nearly as well preserved as in a modern microscopic slide: amber is thus proving once more to be an extraordinary conservative medium.

\section{References}

Bidau CJ. 2014. Patterns in Orthoptera biodiversity. 1. Adaptations in ecological and evolutionary contexts. Journal of Insect Biodiversity 20: 1-39. 
Bomfleur B, Mörs T, Ferraguti M, Reguero MA, McLoughlin S. 2015. Fossilized spermatozoa preserved in a 50-Myr-old annelid cocoon from Antarctica. Biology Letters 11: 30150431.

Breton G. 2012. L'ambre des Corbières (Aude-France). Carcassonne: Société d'Études scientifiques de l'Aude éditions, 96 p.

Kojeta J. 1998. Essays on coccids (Homoptera): sudden death in amber? Polskie Pismo Entomologiczne 67: 185-218.

Matzke-Karasz R, Neil JV, Smith RJ, Symonova R, Mořkovský L, Archer M, et al. 2014. Subcellular preservation in giant ostracod sperm from an early Miocene cave deposit in Australia. Proceedings of the Royal Society B 281: 20140394.

Matzke-Karasz R, Smith RJ, Symonova R, Miller CG, Tafforeau P. 2009. Sexual intercourse involving giant sperm in Cretaceous Ostracode. Science 324: 1535.

Martínez-Delclòs X, Briggs DEG, Peñalver E. 2004. Taphonomy of insects in carbonates and amber. Palaeogeography, Palaeoclimatology, Palaeoecology 203: 19-64.
McLoughlin S, Bomfleur B, Mörs T, Reguero M. 2016a. Fossil clitellate annelid cocoons and their microbiological inclusions from the Eocene of Seymour Island, Antarctica. Palaeontologia Electronica 19.11.11A: 1-27.

McLoughlin S, Bomfleur B, Mörs T. 2016b. The weird world of fossil worm cocoons. Deposits Magazine 43: 15-17.

Poinar Jr. GO. 2000. First fossil record of stalked spermatophore with sperm (Collembola: Haxapoda). Historical Biology 14: 229-234.

Poinar Jr. GO. 2011. The evolutionary history of nematodes. Leiden: Brill, 429 p.

Poinar Jr. GO. 2018. Pygmy mole crickets (Orthoptera: Tridactylidae) in Dominican and Burmese amber. Historical Biology. DOI: $10.1080 / 08912963.2018 .1483362$.

Tuzet O. 1977. Les spermatophores des insectes. In: Grassé PP, ed. Traité de zoologie, anatomie, systématique, biologie, tome VII : Insectes, gamétogenèse, fécondation, métamorphoses. Fasc. V-A. Paris: Masson, $680 \mathrm{p}$.

Cite this article as: Breton G, Poinar G. 2020. Synopsis of rare fossil animal spermatozoa in amber and sedimentary deposits, $B S G F$ - Earth Sciences Bulletin 191: 31. 